\title{
Reproductive and feeding biology of Acestrorhynchus pantaneiro Menezes, 1992 (Osteichthyes: Acestrorhynchidae) in areas under the influence of dams in the upper Uruguay River, Brazil
}

\author{
Samira Meurer and Evoy Zaniboni-Filho
}

The reproductive and feeding biology of Acestrorhynchus pantaneiro were studied in the upper Uruguay River, southern Brazil. Fourteen sites were surveyed seasonally between 2000 and 2006. A total of 3,427 fish were caught, being 2,015 females and 1,412 males. The sex ratio was 1.66:1 (female:male) in lentic habitats $(\mathrm{p}<0.05)$, but showed equal proportion in lotic and transition habitats. Feeding activity was similar for both sexes and showed little variation along the year. The analysis of stomach contents of 2,401 stomach showed that "fish" was the most consumed resource in all different habitats, corresponding to $99 \%$ of the food in the gravimetric analyzes. The species showed a multiple spawning type with a long reproductive period, although the highest intensity of reproduction occurred between the beginning of spring and summer, marked by the highest GSI and advanced gonadal maturity stages. Relative fecundity (mean \pm SD) was $139 \pm 56$ oocytes per mm of total length and $152 \pm 66$ oocytes per gram of total weight. The mean absolute fecundity was 33,470 $\pm 19,151$ oocytes and the average of the mature oocytes diameter was $897.5 \pm 365.4 \mu \mathrm{m}$. Acestrorhynchus pantaneiro is more abundant in lentic environments and presents biological characteristics that favor the establishment of the species in dammed rivers.

A biologia reprodutiva e alimentar do peixe-cachorro Acestrorhynchus pantaneiro foi avaliada na região do alto rio Uruguai, sul do Brasil. Um total de 3.427 exemplares foram capturados, em 14 estações amostradas sazonalmente no período entre 2000 e 2006. Destes, 2.015 eram fêmeas e 1.412 machos. A proporção sexual nos ambientes lênticos foi de 1,66:1 (fêmeas:machos) $(\mathrm{p}<0,05)$, apresentando proporções semelhantes nos ambientes lóticos e de transição lótico-lêntico. A atividade alimentar foi semelhante entre os sexos e apresentou pequena variação ao longo do ano. A análise de 2.401 estômagos revelou que a espécie alimentou-se predominantemente da categoria "peixe" em todos os ambientes amostrados, representando $99 \%$ do alimento pela análise gravimétrica. O período reprodutivo é longo e se estende por quase todo o ano, embora esteja mais concentrado entre o início da primavera e o verão, quando foram observados os maiores valores da relação gonadossomática e dos estádios avançados de maturação gonadal. A desova é do tipo parcelada. A fecundidade absoluta (média \pm DP) é de $33.470 \pm 19.151$ ovócitos, enquanto a fecundidade relativa é de $139 \pm 56$ ovócitos $/ \mathrm{mm}$ e $152 \pm 66$ ovócitos/g. O diâmetro médio dos ovócitos maduros é de 897,5 $\pm 365,4 \mu \mathrm{m}$. Acestrorhynchus pantaneiro é mais abundante nos ambientes lênticos e apresenta características biológicas que favorecem o estabelecimento da espécie em ambientes formados pelo represamento dos rios.

Key words: Feeding dynamic, Peixe-cachorro, Reproductive dynamic, Saicanga.

\section{Introduction}

The high behavioral plasticity shown by most Neotropical fish species, especially related to reproductive and feeding strategies, can prevent large-scale extinction of species following impoundment, although changes in the composition and structure of fish assemblages are inherent to the formation of this new environment (Agostinho et al., 2007). These changes are so strong that Baxter (1977) suggested that they are equivalent to the formation of a new ecosystem. Besides feeding flexibility, species inhabiting reservoirs need to have previous reproductive adaptations to lentic environments, since reproductive strategies are, in general, more conservative than feeding strategies. Thus, previous reproductive adaptation is the most important characteristic for a successful establishment in reservoirs (Agostinho et al., 2007).

The saicanga or peixe-cachorro, Acestrorhynchus pantaneiro Menezes, 1992, is a medium-sized Acestrorhynchidae very abundant in the Itá Reservoir area. It was the eigh ${ }^{\text {th }}$ most abundant species captured during surveys

Universidade Federal de Santa Catarina, Laboratório de Biologia e Cultivo de Peixes de Água Doce (LAPAD/CCA/UFSC), Rodovia SC 406, n 3532, Armação, 88066-000 Florianópolis, SC, Brazil. samixam@hotmail.com (SM) 
carried out in the region of the upper Uruguay River after the impoundment of Itá Reservoir (Zaniboni-Filho et al., 2008). The upper Uruguay River has been target of dam constructions since December 1999, and before Itá Reservoir construction $A$. pantaneiro was only the $59^{\text {th }}$ more abundant species in that area (Zaniboni-Filho et al., 2008), among 98 species reported in the region of the upper Uruguay River (Zaniboni-Filho et al., 2004). Acestrorhynchus pantaneiro is an important fish species due its role as predator in the aquatic food web (Bennemann et al., 2000; Catanhêde et al., 2008; Krinski, 2010). Furthermore, considering that impacts of damming are of distinct nature and intensity (Agostinho et al., 2007), studies on the biology of fishes are essential to improve habitat and fish population management. The goals of the present study were to evaluate the feeding and the reproductive biology of $A$. pantaneiro in an area under influence of impoundments in the upper Uruguay River. This knowledge can provide important tools for fish management and help us to understand the causes of population increases after river impoundment. For this, we investigated the feeding and reproductive dynamic during seasonal periods and different habitats to understand the abilities of the species to colonize reservoirs.

\section{Material and Methods}

Study area. The Uruguay River runs 2,262 km before discharging into the La Plata estuary, of which the Paraná and Paraguay Rivers are also part (Di Persia \& Neiff, 1986). Samplings were carried out within approximately 430-km stretch of the upper Uruguay River, including Itá and Machadinho Reservoirs.

The Itá Reservoir was formed in December 1999, it has an area of $141 \mathrm{~km}^{2}$ and the average time of water residence is 57 days. Upstream of the Itá Reservoir is Machadinho Dam. Between these two impoundments, there is a small lotic stretch of approximately $10 \mathrm{~km}$. Machadinho Reservoir was formed in October 2001, it has an area of $79 \mathrm{~km}^{2}$ and an average time of water residence of 53 days.

Fish sampling. Samplings were carried out every three months between October 2000 and August 2006. Fourteen sampling sites were evaluated (Fig. 1), including the Uruguay River and some of its main tributaries, and Itá and Machadinho reservoirs. To evaluate the influence of the hydrological characteristics, sites were grouped into three categories, according of the water dynamics of the site (lentic, lotic, and transition between river and reservoir condition): seven sites were located within the main body of the reservoirs (Lentic sites: $\mathrm{PB}=$ Pelotas Barracão, $\mathrm{Z}=$ Zortea, $\mathrm{F}$ $=$ Forquilha, $\mathrm{RG}=$ Rancho Grande, $\mathrm{BQ}=$ Barra dos Queimados, $\mathrm{BR}=\mathrm{BR}-153$, IV = Itá Velha); four sites were located in running water areas (Lotic sites: $\mathrm{PT}=$ Pelotas Túneis, $\mathrm{L}=$ Ligeiro, $\mathrm{P}=$ Palomas, $\mathrm{FC}=$ Foz do Chapecó); and three sites were located in transitional areas between the river and the reservoir (Transition sites: $\mathrm{C}=$ Canoas, $\mathrm{PX}=$ Peixe, $\mathrm{MR}=$ Marcelino Ramos).
Fish were sampled by a set of gillnets with different mesh sizes (1.5, 2.0, 2.5, and $3.0 \mathrm{~cm}$ between adjacent knots), $30 \mathrm{~m}$ length and $1.8 \mathrm{~m}$ height. Cast net, hook and line, and seine were also used. Gillnets and hook and line were set in the evening (18:00 $\mathrm{h})$ and removed in the following morning (6:00 h), fishing for $12 \mathrm{~h}$ periods. For each sample, cast net was used 10 times and seine 3 times per site, always during day time. Fishing effort was the same in all sampling sites and throughout the study period. Voucher specimens were sent to the Zoological Museum of the Londrina State University ( MZUEL 5777).

Feeding analysis. After the capture and taxonomic identification, all Acestrorhynchus pantaneiro were weighed (in grams), measured (total length in $\mathrm{mm}$ ) and dissected to register stomach weight (in grams). All stomachs were preserved in $4 \%$ formalin. After one or two months in formalin, stomachs were transferred to $70 \%$ ethanol where they were kept until processing for diet analysis. The stomach repletion index (SRI) was estimated following the formula: SRI $=\mathrm{Ws} / \mathrm{Wt}$ $\mathrm{X} 100$, where Ws corresponds to stomach weight and Wt to total fish weight.

Stomach contents were examined and identified under a stereo microscope and/or microscope, when necessary. The diet of $A$. pantaneiro was evaluated based on the frequency of occurrence (Hyslop, 1980) and the gravimetric methods (in grams) (Hyslop, 1980).

For this analysis, food items were weighted (with precision of milligrams) and classified into seven categories of fish resources (Cichlidae, Characidae, Curimatidae, Gymnotidae, Parodontidae, Pimelodidae, and non-identified fish), and three other categories: insects, organic matter (detritus and digested material), and inorganic matter.

Reproductive analysis. The reproductive dynamic was evaluated through macroscopic analysis of gonadal stages in the field. Gonadal maturation stages were classified based on coloration, vascularization, gonad relative size to the abdominal cavity, gonad flaccidity, and oocyte size. Five gonadal maturation stages (GMS) were determined according to Vazzoler (1996): Immature (I), Maturing (Mn), Mature (Mt), Spent (S), and Regression (R). The reproductive period for males and females was established through analysis of the temporal distribution of Gonadosomatic Index (GSI). The gonadosomatic ratio was calculated through the expression: $\mathrm{GSI}=\mathrm{Wg} / \mathrm{Wt}$ X 100, where Wt corresponds to total fish weight and $\mathrm{Wg}$ to gonadal weight. The sex ratio was determined using the absolute frequencies of males and females during the sampling period, considering separately lentic, lotic, and transitional habitats.

Ovary samples from 45 mature females were immersed in Gilson's solution to estimate absolute fecundity (Vazzoler, 1996) by counting all vitellogenic oocytes. The relative fecundity was calculated by considering the absolute fecundity per unit weight and length of each fish. To determine spawning type, the frequency of occurrence of oocyte diameter was investigated in 56 females. From each female, a 


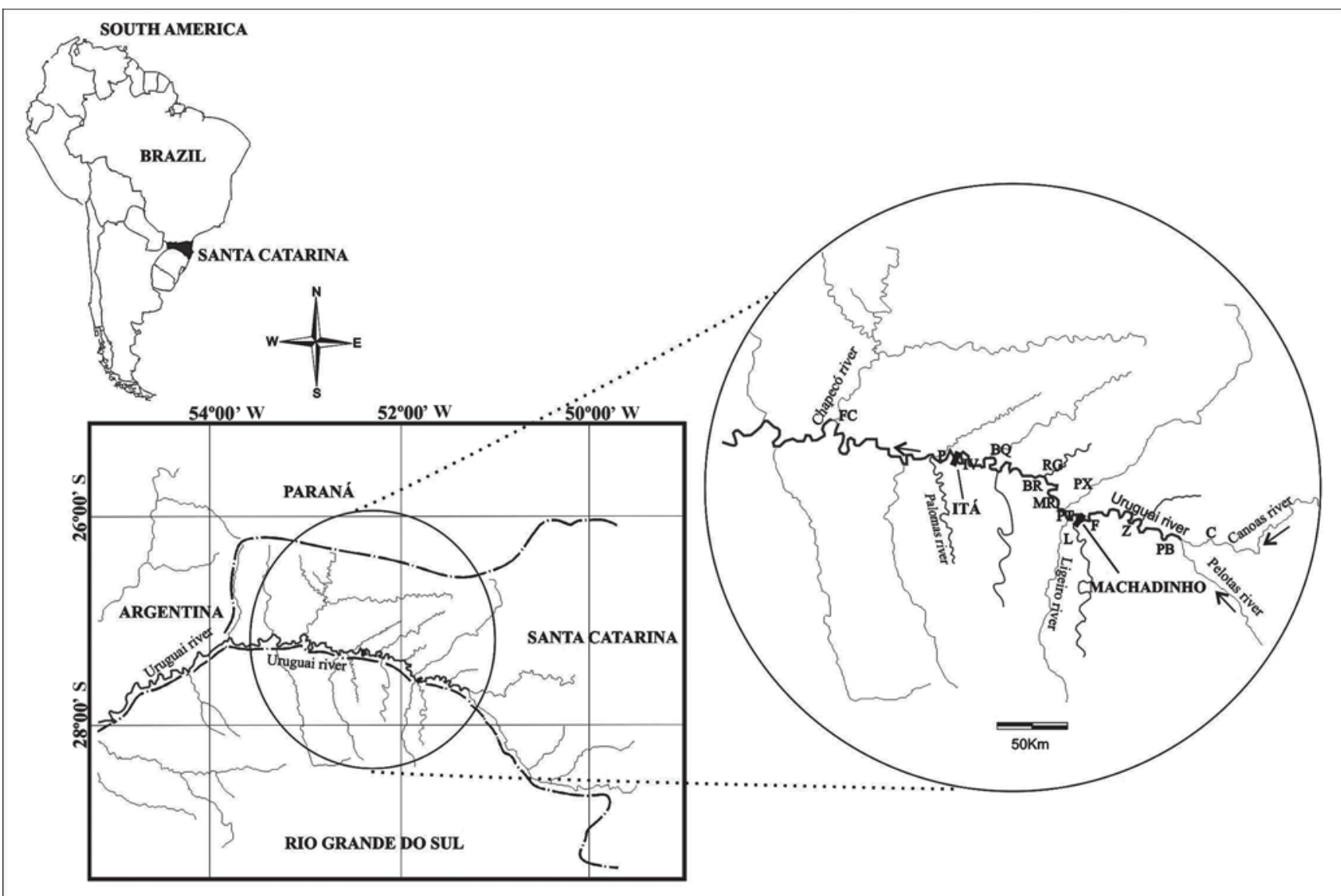

Fig. 1. Location of sampling sites in the upper Uruguay River. $P B=$ Pelotas Barracão, $Z=$ Zortea, $F=F$ orquilha, $R G=R a n c h o$ Grande, $\mathrm{BQ}=$ Barra dos Queimados, $\mathrm{BR}=\mathrm{BR}-153$, IV = Itá Velha; $\mathrm{C}=$ Canoas, $\mathrm{PX}=$ Peixe, $\mathrm{MR}=$ Marcelino Ramos, $\mathrm{PT}=\mathrm{Pelotas}$ Túneis, $\mathrm{L}=$ Ligeiro, $\mathrm{P}=$ Palomas, and $\mathrm{FC}=$ Foz do Chapecó.

sub-sample of 500 oocytes was measured for the determination of the minimum size of the mature oocytes. This minimum vitelogenic oocyte size was $250 \mu \mathrm{m}$ and, according to Vazzoler (1981), the value of the minimum vitelogenic oocyte size can be used to separate the oocytes from the gonad that probably could be released in the next spawning event. The number of oocytes bigger than the minimum vitelogenic oocyte size (250 $\mu \mathrm{m})$ was used to estimate absolute fecundity for each female.

Statistical analyses. Length classes were determined to verify size differences between sexes, through Sturges rule (Sturges, 1926). To analyze the influence of the water dynamic on fish abundance, sex ratio and diet, sampling sites were grouped according to their hydrological condition (lentic, lotic, and transition). The Chi-square test $(\mathrm{p}=0.05)$ was used to analyze sex ratio among grouped sites.

\section{Results}

A total of 3,427 specimens of $A$. pantaneiro was captured: 2,015 females and 1,412 males. Total length varied between 11.8 and $37.9 \mathrm{~cm}(26.5 \pm 3.4 \mathrm{~cm})$ (mean \pm standard deviation) for females and between 7.6 and $33 \mathrm{~cm}(20.5 \pm 2.7 \mathrm{~cm})$ for males.
Total weight varied between 28 and $396 \mathrm{~g}(167.4 \pm 59.9 \mathrm{~g})$ for females and between 11 and $328 \mathrm{~g}(72.5 \pm 31.6 \mathrm{~g})$ for males. The frequency distribution of size grouped by sex showed larger sizes for females (Fig. 2).

The evaluation of the abundance of $A$. pantaneiro in different sampling sites showed an influence of the hydrological characteristics of the site on the abundance of this species, which was predominant in lentic environments (Fig. 3).

A predominance of females was observed in the lentic sites $(p<0.05)$ (Fig. 4), showing a sex ratio of 1.66:1. In lotic and transitional environments sex ratio was similar between males and females.

A total of 2,401 stomachs were removed and examined, but only $14.7 \%$ of these contained some food. No evidence of regurgitation was observed during fish capture. Thus, the stomach contents of 353 specimens with lengths varying between 122 and $325 \mathrm{~mm}$ and weights between 22 and $309 \mathrm{~g}$ were analyzed. Figure 5 is the graphical representation of the frequency of occurrence $(\mathrm{FO} \%)$ and gravimetric $(\mathrm{G} \%)$ analyzes of the main food items, except organic (OM) and inorganic matter (IM). Among the food resources presented in the diet, "fish" was the most consumed in all sites. "Fish" was observed in more than $90 \%$ of the analyzed stomachs 


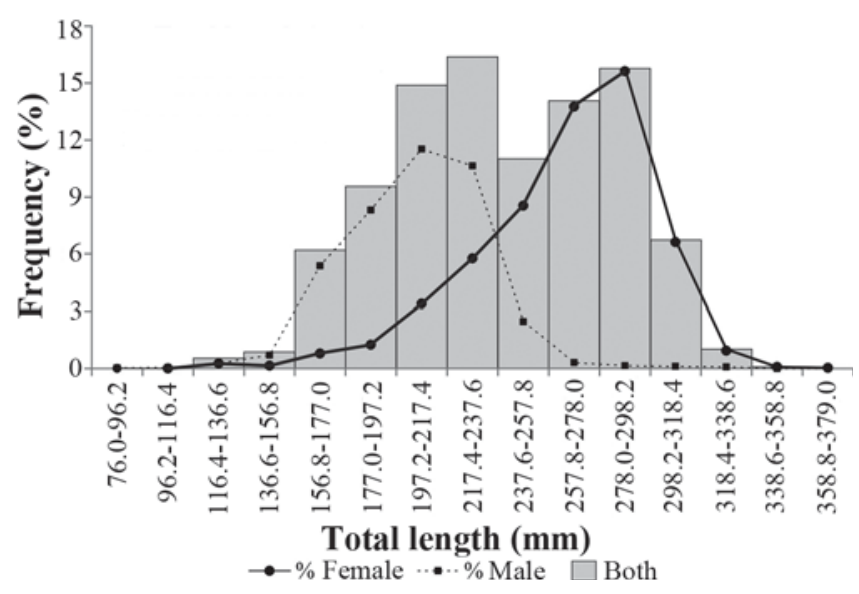

Fig. 2. Frequency of Acestrorhynchus pantaneiro grouped by length classes (mm) (bars) and separated by sex (lines).

and represented $99 \%$ in the gravimetric analyzes (Fig. 5). The other categories presented an insignificant participation, and the gravimetric percentage for organic $(\mathrm{OM})$ and inorganic matter (IM) were: $0.0 \% ; 0.0 \%, 0.1 \%(\mathrm{OM})$ and $0.0 \% ; 0.0 \%$; $0.3 \%$ (IM) in lentic, transitional and lotic sites, respectively. Fish of the family Characidae were the most consumed in lentic and lotic environments, and also presented the highest values in the gravimetric analyzes, $37.3 \%$ and $40.1 \%$ respectively. In transitional sites, fish of the family Curimatidae were most frequent and presented the highest percentage in the gravimetric analyzes $(21.5 \%)$, and Characidae was the second fish prey in FO and in the gravimetric percentage (18.5\%). Considering A pantaneiro from all environments together, using gravimetric analyzes and presenting in order of importance, fish of the family Characidae (33.2\%), Curimatidae (9.2\%), Cichlidae (6.8\%), Gymnotidae (4.4\%),

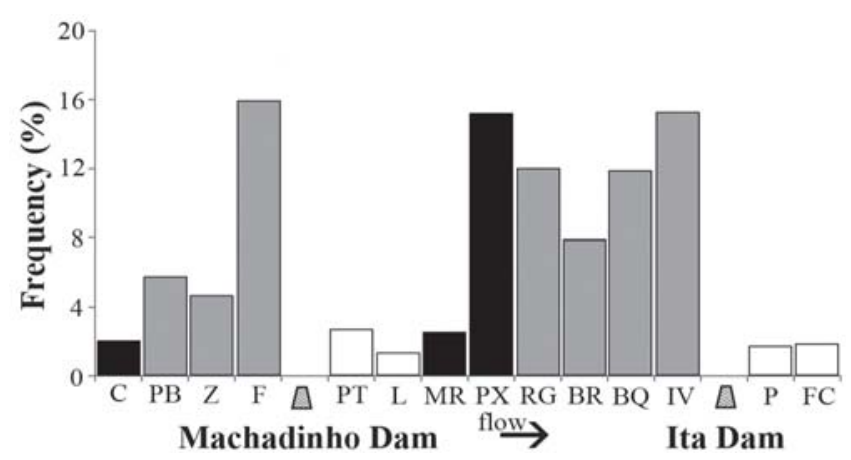

Fig. 3. Relative abundance of Acestrorhynchus pantaneiro captured at different sampling sites (Lentic [gray bars]: $\mathrm{PB}=$ Pelotas Barracão, $Z$ = Zortea, $F=$ Forquilha, $R G=$ Rancho Grande, $\mathrm{BQ}=$ Barra dos Queimados, $\mathrm{BR}=\mathrm{BR}-153$, IV = Itá Velha; Transition [black bars]: $\mathrm{C}=$ Canoas, $\mathrm{PX}=$ Peixe, $\mathrm{MR}=$ Marcelino Ramos, Lotic [white bars]: PT = Pelotas Túneis, L = Ligeiro, $\mathrm{P}=$ Palomas, $\mathrm{FC}=$ Foz do Chapecó).

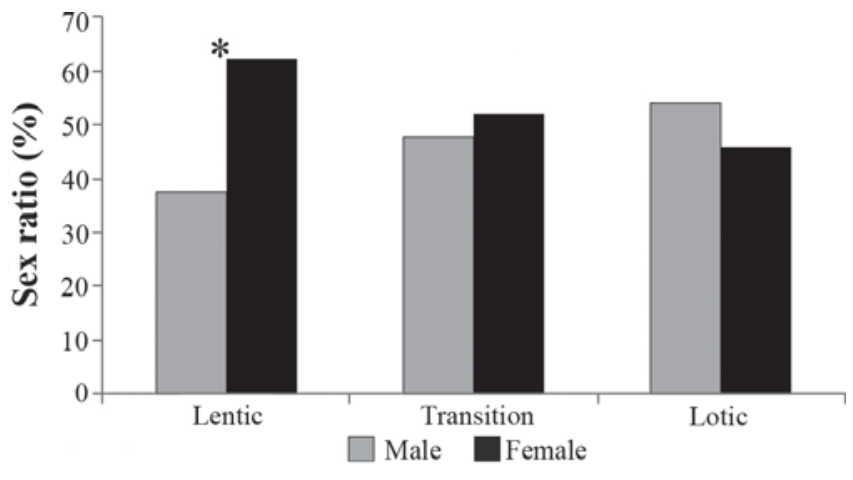

Fig. 4. Sex ratio of $A$. pantaneiro captured in different hydrological conditions in the upper Uruguay River between October 2000 and August 2006 (* indicates a statistically significant difference at the 5\% level - Chi-square).

Pimelodidae (1.8\%), and Parodontidae (1.2\%) were the most important resources. Among food items that could be identified to the generic or specific level, the lambaris: Astyanax jacuhiensis, Bryconamericus spp., Astyanax spp., the biru Steindachnerina brevipinna, and the canivete Apareiodon affinis were observed.

Stomach repletion index demonstrated short variation along the year, indicating that males and females of $A$. pantaneiro maintain similar feeding activity during the year, even in the period of highest reproductive activity (Table 1).

The species were observed to reproduce in a long period of the year, but the reproductive activity was highest during spring, followed by summer, as evidenced by the high GSI values for both sexes (Fig. 6) and the high frequency of mature female (Fig. 7). During all seasons of the year, both males and females in the maturing stage (Mn) were observed, whereas mature specimens $(\mathrm{Mt})$ were more frequent in the spring, followed by the summer (Fig. 7).

It was observed the presence of different sizes of vitelogenic oocytes in the mature gonads of $A$. pantaneiro, indicating that the species presents multiple or parceled spawning strategy.

Absolute fecundity (average \pm SD) was 33,470 $\pm 19,151$ oocytes, and relative fecundity was $139 \pm 56$ oocytes per millimeter of total length and $152 \pm 66$ oocytes per gram unity of total weight. Mature oocytes presented an average diameter of $897.5 \mu \mathrm{m}$.

\section{Discussion}

The higher abundance of $A$. pantaneiro in lacustrine environments in the studied area, followed by transition and lotic environments, is similar to the distribution of $A$. lacustris near the Itaipu Reservoir, according to Hahn et al. (2000). The predominance of females in lentic sites and the higher abundance of peixe-cachorro in lentic waters indicate that $A$. pantaneiro is well adapted to colonize impounded areas. The importance of $A$. pantaneiro changed from $0.06 \%$ 

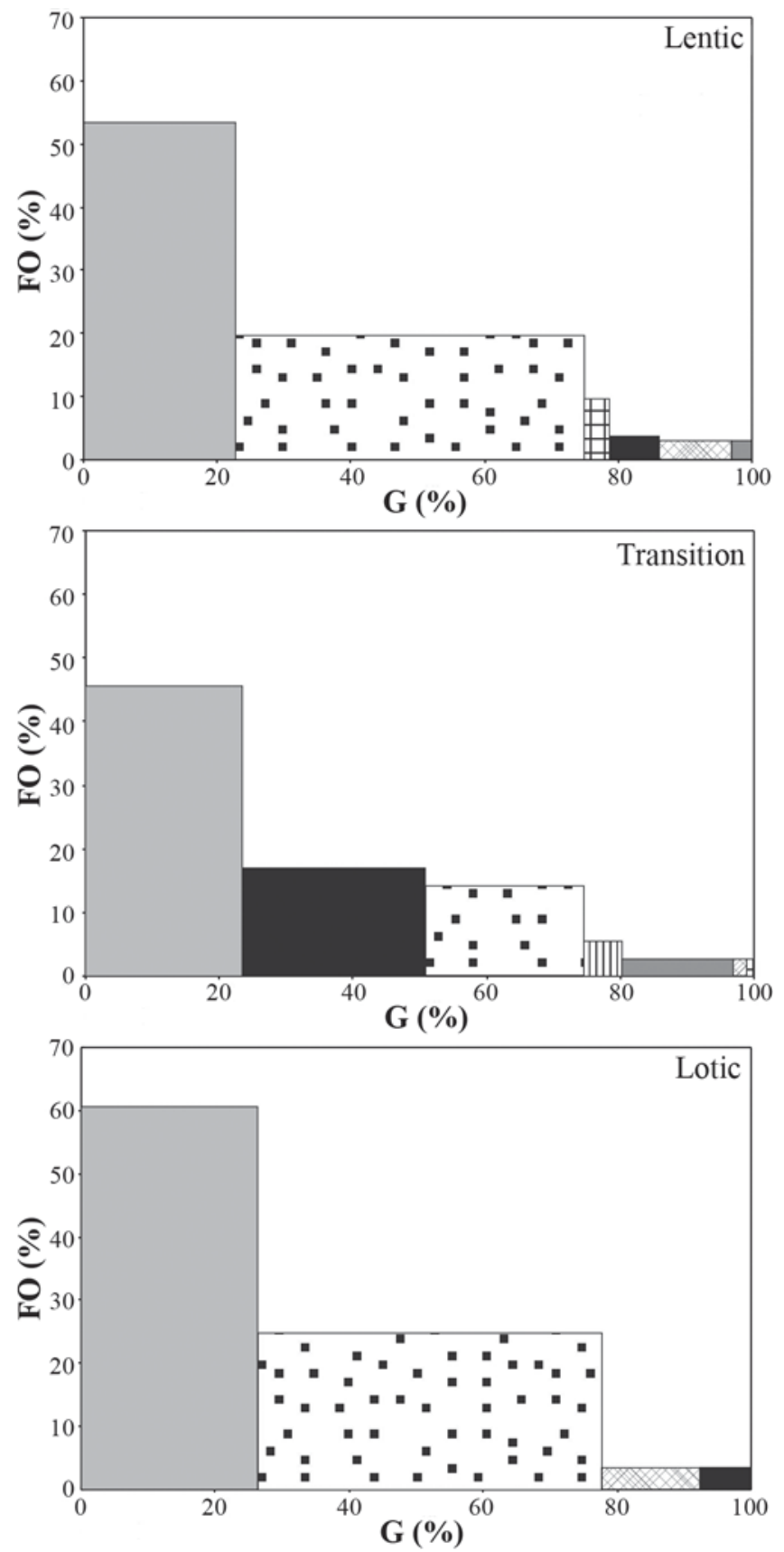

Non-identified fish $\boxplus$ Pimelodidae $\otimes$ Cichlidae 血 Parodontidae Gymnotidae Curimatidae Insect

Fig. 5. Categories of food items observed in A. pantaneiro according to the frequency of occurrence (FO\%) and gravimetric ( $\mathrm{G} \%$ ) methods in different hydrological conditions. The number of analyzed stomachs is 228 in lentic sites, 73 in transition and 52 in the lotic sites.

of the total fish biomass per unit of effort before the construction of Itá Dam to $7.80 \%$ after the formation of the reservoir (Zaniboni-Filho et al., 2008). The increase in 130 times in biomass shows its success in the colonization of this reservoir, which can be attributed to the reproductive
Table 1. Seasonal Stomach Repletion Index (SRI) (mean \pm $\mathrm{SD})$ by sex of Acestrorhynchus pantaneiro in the upper Uruguay River.

\begin{tabular}{ccccc}
\hline Sex/Season & Spring & Summer & Autumn & Winter \\
\hline Females & $2.24 \pm 2.35$ & $2.11 \pm 1.85$ & $1.84 \pm 2.16$ & $2.10 \pm 1.93$ \\
Males & $1.64 \pm 1.60$ & $1.57 \pm 1.53$ & $1.91 \pm 1.96$ & $1.71 \pm 1.47$ \\
\hline
\end{tabular}

and food strategies of the species. The great food availability created by the proliferation of small-sized species, a common characteristic of newly formed reservoirs, probably propitiated an abundance of food for A. pantaneiro.

In addition to giving important information about the characterization of a specific population structure, the sex ratio constitutes an important tool for the study of other aspects, such as the evaluation of the reproductive potential and the estimation of stock size (Vazzoler, 1996). Although the classic sex ratio of fish is 1:1 (Wootton, 1999), it can vary considerably between species, as well as between populations of one species inhabiting different environments (Nikolsky, 1978). Different environmental conditions (particularly in terms of food supply) would be reflected in mortality rates and/or differential growth for females and males, resulting in variation in the sex ratios not only for different length classes but also for the whole population. In the region of the upper Uruguay River, the abundance of females was higher (1.66:1) only in lentic environments. The sex ratio was similar in lotic sites and transitional areas between the river and the reservoir. Moreover, the sex structure can represent an adaptation to the food supply that may favor the increase of the ratio of females to males (Nikolsky, 1969).

Knowledge of the food resources that are available to fish populations and possible variations in their diets is an initial step to understand the processes involved in the establishment of the species in reservoirs (Abelha et al., 2006). Studies with A. pantaneiro in the Pantanal Matogrossense demonstrate that this species feeds on shrimp and fish in the same ratio (Resende et al., 1996), whereas in the Tibagi River, another species of peixe-cachorro, A. lacustris, includes in its diet, although accidentally, plants and insects (Benneman,1996). In the Itaipu

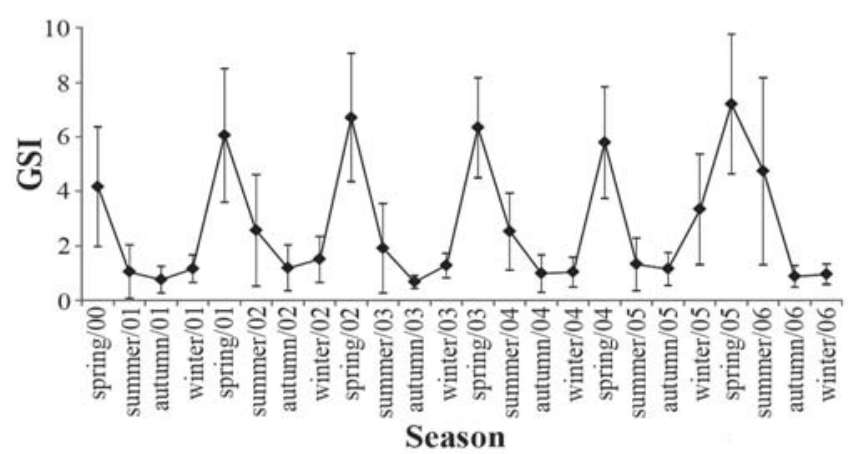

Fig. 6. Seasonal variation of Gonadossomatic Index (GSI) (mean $\pm \mathrm{SD}$ ) for males and females of Acestrorhynchus pantaneiro in the upper Uruguay River. 

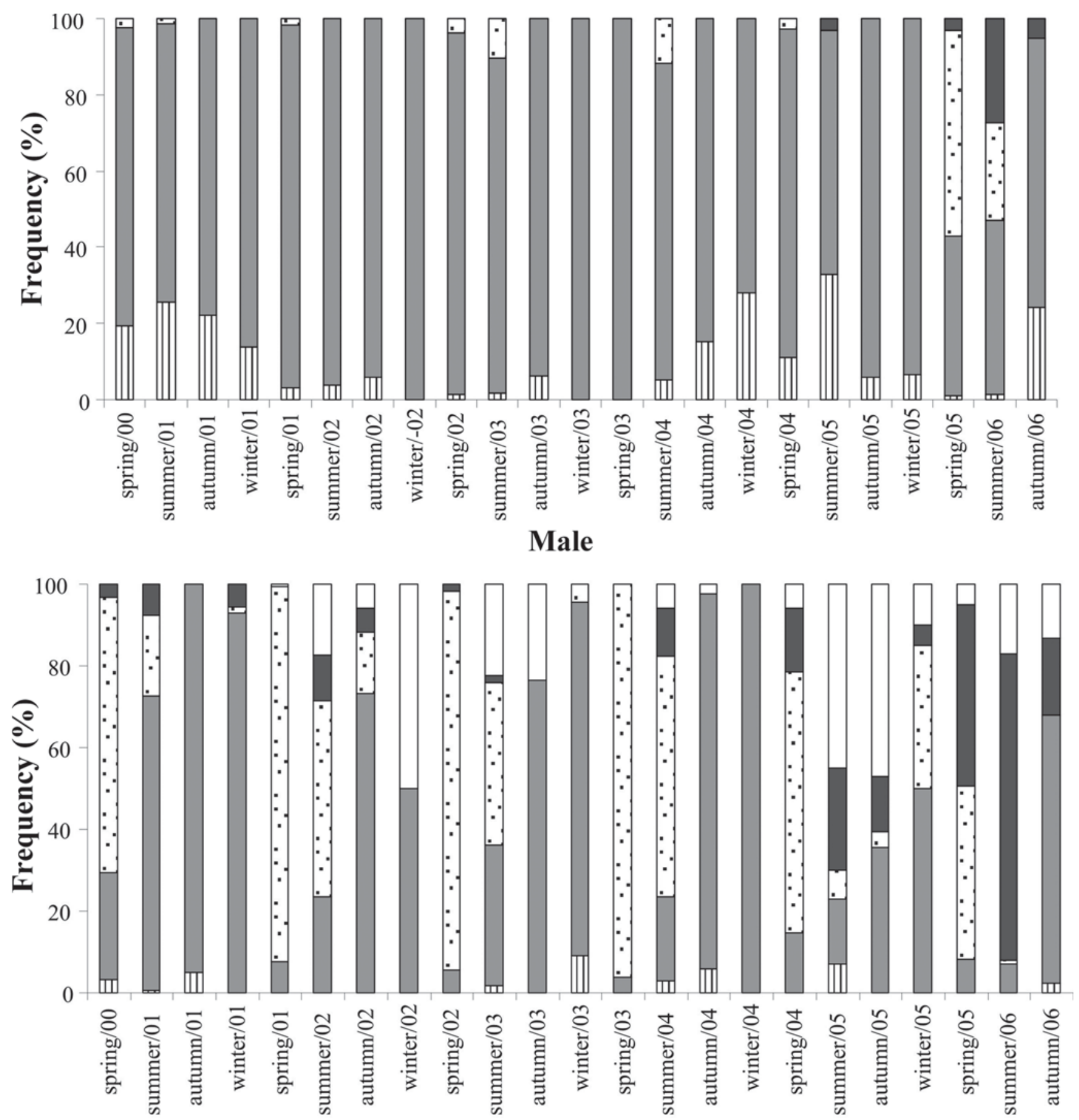

Female

四 $\mathrm{I} \quad \square \mathrm{Mn} \square \mathrm{Mt} \square \mathrm{S} \square \mathrm{R}$

Fig. 7. Seasonal abundance (\%) of the gonadal maturation stages for males and females of Acestrorhynchus pantaneiro in the upper Uruguay River.

(Hahn et al., 2000), Capivara (Teixeira \& Bennemann, 2007), and Três Marias (Peret, 2004) Reservoirs, A. pantaneiro consumed exclusively fish, although Peret (2004) observed that the species changed its feeding habits according to fish availability. Although in this study A. pantaneiro consumed mainly fish, the species has demonstrated flexibility and changed the main fish prey in different environments, which seems to be a characteristic common to other species of this genus. Cantanhêde et al. (2008) also verified that $A$. pantaneiro presented a piscivorous behavior but was able to change its diet to consume the most abundant prey in the Manso Reservoir (Mato Grosso State, Brazil). In the present study, the main 
groups of fish consumed by A. pantaneiro were among the ten most numerically abundant in the region of the upper Uruguay River, according Zaniboni-Filho et al. (2008). Although $A$. pantaneiro consumed other resources besides fish, such resources can be considered accidental, since together they summed less than $1 \%$ of the diet. Thus, this species can be considered as a piscivore.

Being of a quantitative nature, the repletion index can supply reliable information to indicate the period of highest feeding activity (Barbieri, 1992). Both males and females of $A$. pantaneiro captured in the region of the upper Uruguay River presented little variation in their average of stomach repletion indices throughout the year, indicating that the species does not interrupt its feeding activity, even during high reproductive activity. Another strategy that allowed the extensive propagation of $A$. pantaneiro in the studied area is the presence of multiple spawnings. A common characteristic of species that inhabit lakes and reservoirs (Bazzoli, 2003), multiple or parceled spawning represents a mechanism through which a species can increase the number of oocytes produced in a reproductive cycle (Vazzoler, 1996). Thus, the adaptation to the available food resources, in addition to its type of spawning, allowed $A$. pantaneiro to find excellent conditions for its establishment in the impounded area, resulting in its fast dissemination.

The reproductive period seemed to concentrate in the spring and summer, but there is some reproductive activity throughout the year, as evidenced by the presence of mature specimens in all seasons. Despite this, it seems that the reproductive period varies from year to year, which is probably related to environmental changes. Mature and spent females were registered in the winters of 2001, 2003, and 2005, albeit in small numbers. Lopes et al. (2000) also reported cyclical changes in the duration and intensity of the reproductive period for Leporinus friderici in the Itaipu Reservoir. Acestrorhynchus pantaneiro presented a long reproductive period, similar to other species of peixe-cachorro, such as Galeocharax knerii (Magalhães et al., 2004). Beyond this characteristic, the absence of parental care indicates an opportunistic reproductive strategy, allowing the species to colonize most reservoirs of southeastern Brazil (Magalhães et al., 2004; Benedito-Cecílio \& Agostinho, 2000).

The average absolute fecundity of $A$. pantaneiro was 33,470 oocytes $( \pm 19,151)$. TThis value can be considered relatively high when compared to other species of peixecachorro with similar trophic and reproductive strategies, such as Oligosarcus jenynsii $(17,684)$ studied in the Caconde lagoon of the Rio Grande do Sul State (Hartz et al., 1997). The same species, $O$. jenynsii, and another, $O$. robustus, studied in another lagoon of the Rio Grande do Sul, also presented lower average absolute fecundities of 14,483 and 16,308, respectively (Nunes et al., 2004). Fialho et al. (1998), analyzing O.jenynsii in the Custódias Lagoon, also in the Rio Grande do Sul State, reported an average absolute fecundity of 9,694 oocytes. Acestrorhynchus pantaneiro presented mature oocytes with an average diameter of $897.5 \mu \mathrm{m}$, smaller than that observed for $O$. jenynsii of 1,300 $\mu \mathrm{m}$ (Hartz et al., 1997). As a general rule, in addition to the inverse relationship between the oocyte size and absolute fecundity, the size of the female also influences the number of oocytes produced, which increases with fish size. On the other hand, the analysis of relative fecundity aims to reduce the influence of body size on fecundity, allowing comparisons between specimens of different sizes (Giora, 2004).

Acestrorhynchus pantaneiro in the present study demonstrated opportunistic reproductive and feeding behavior (multiple spawning, ability to prey different fish species, and tolerate distinct hydrological conditions). Additionally, the species presents a long reproductive period and consumed the most abundant fish species. These characteristics have allowed this species to quickly colonize the area influenced by the analyzed reservoirs.

\section{Acknowledgements}

The authors acknowledge CAPES, CNPq, FAPESC, Tractebel Energia, and Consórcio Machadinho for financial support; field technicians Pedro Iaczinsk, Maurício Machado and Ronaldo da Silva for their assistance with fieldwork; Michele Nunes Cavalheiro for her assistance with the analyses; and Samara Hermes-Silva for her assistance with English revision and figures construction.

\section{Literature Cited}

Abelha, M. C. F., E. Goulart, E. A. L. Kashiwaqui \& M. R. Silva. 2006. Astyanax paranae Eigenmann, 1914 (Characiformes: Characidae) in the Alagados Reservoir, Paraná, Brazil: diet composition and variation. Neotropical Ichthyology, 4: 349-356.

Agostinho, A. A., L. C. Gomes \& F. M. Pelicice. 2007. Ecologia e manejo de recursos pesqueiros em reservatórios do Brasil. Maringá, EDUEM, 501p.

Barbieri, G. 1992. Dinâmica da nutrição de Astyanax scabripinnis paranae (Characiformes, Characidae) do Ribeirão do Fazzari: São Carlos, SP. Revista Brasileira Zoologia, 21: 68-72.

Baxter, R. M. 1977. Environmental effects of dams and impoundments. Annual Review of Ecology and Systematics, 8: 255-283.

Bazzoli, N. 2003. Parâmetros reprodutivos de peixes de interesse comercial do rio São Francisco na região de Pirapora, Pp. 285300. In: Godinho, H. P. \& A. L. Godinho (Eds.). Águas, peixes e pesca no São Francisco das Minas Gerais. Belo Horizonte, Ed. PUC, 438p.

Benedito-Cecílio, E. \& A. A. Agostinho. 2000. Distribution, abundance and use of different environments by dominant ichthyophauna in the influence real of Itaipu Reservoir. Acta Scientiarium, 22: 429-437.

Benneman, S. T. 1996. Dinâmica trófica de uma assembléia de peixes de um trecho do rio Tibagi (Sertanópolis-Paraná). Unpublished Ph.D. Dissertation, Universidade Federal de São Carlos, São Paulo, 144p.

Benneman, S. T., O. A. Shibatta \& J. C. Garavello. 2000. Peixes do rio Tibagi: uma abordagem ecológica. Londrina: Eduel, 62p.

Castanhêde, G., N. S. Hahn, R. Fugi \& E. A. Gubiani. 2008. Alterations on piscivorous diet following change in abundance 
of prey after impoundment in a Neotropical river. Neotropical Ichthyology, 6: 631-636.

Di Persia, D. H. \& J. J. Neiff. 1986. The Uruguay River System. Pp. 599-621. In: Davies, B. R.; K. F Walker (Eds.). The Ecology of River System. Dordrecht, The Netherlands: Dr. W. Junk Publishers, 816p.

Fialho, C. B., L. C. Schifino \& J. R. Verani. 1998. Biologia reprodutiva de Oligosarcus jenynsii (Günther) (Characiformes, Characidae) da Lagoa das Custódias. Tramandaí, Rio Grande do Sul, Brasil. Revista Brasileira de Zoologia, 15: 775-782.

Giora, J., C. B. Fialho \& A. P. S. Dufech. 2005. Feeding habit of Eigenmannia trilineata Lopez \& Castello, 1966 (Teleostei: Sternopygidae) of Parque Estadual de Itapuã, RS, Brazil. Neotropical Ichthyology, 3: 291-298.

Hahn, N. S., R. L. Delariva \& V. E. Loureiro. 2000. Feeding of Acestrorhynchus lacustris (Characidae): a post impoundment studies on Itaipu Reservoir, Upper Paraná River, PR. Brazilian Archives of Biology and Tecnology, 43, 207-213.

Hartz, S. M., F. S. Vilella \& G. Barbieri. 1997. Reproduction dynamics of Oligosarcus jenynsii (Characiformes, Characidae) in Lake Caconde, Rio Grande do Sul, Brasil. Revista Brasileira de Biologia, 57: 295-303.

Hyslop, E. J. 1980. Stomach contents analysis, a review of methods and their application. Journal of Fish Biology, 17: 411-429.

Lopes, C. A., E. Benedito-Cecílio \& A. A. Agostinho. 2000. The reproductive strategy of Leporinus friderici (Characiformes, Anostomidae) in the Paraná River Basin: the effect of reservoirs. Revista Brasileira de Biologia, 60: 2-14.

Magalhães, A. L. B., N. Bazzoli, G. B. Santos \& E. Rizzo. 2004. Reproduction South American dogfish characid, Galeocharax knerii, in two reservoirs from upper Paraná River basin, Brazil. Environmental Biology of Fish, 70: 415-425.

Nikolsky, G. V. 1969. Theory of fish population dynamics as the biological background for rational exploitation and management of fishery resources. Edinburg, Oliver \& Boyd Ltda, 323p.

Nikolsky, G. V. 1978. The ecology of fishes. T. F. H. Publications, Neptune City.
Nunes, D. M., M. Pellanda \& S. M. Hart. 2004. Dinâmica reprodutiva de Oligosarcus jenynsii e O. robustus (Characiformes, Characidae) na lagoa Fortaleza, Rio Grande do Sul, Brasil. Iheringia, Série Zoologia, Porto Alegre, 94: 5-11.

Peret, A. M. 2004. Dinâmica da alimentação de peixes piscívoros da represa de Três Marias (MG). Unpublished Ph.D. Dissertation, Universidade Federal de São Carlos, São Carlos, 60p.

Resende, E. K., R. A. C. Pereira, V. L. L. Almeida \& A. G. Silva. 1996. Alimentação de peixes carnívoros da planície inundável do rio Miranda, Pantanal, Mato Grosso do Sul, Brasil. Corumbá, MS, EMBRAPA-CPAP, Boletim de Pesquisa, 3, 36p.

Sturges, H. A. 1926. The choice of a class interval. Journal of the American Statistical Association, 21: 65-66.

Teixeira, I. \& S. T. Bennemann. 2007. Ecomorfologia refletindo a dieta dos peixes em um reservatório no sul do Brasil. Biota Neotropica, 7: 67-76.

Vazzoler, A. E. A. M. 1981. Manual de métodos para estudos biológicos de populações de peixes: reprodução e crescimento. Brasília, CNPq. Programa Nacional de Zoologia, 108p.

Vazzoler, A. E. A. M. 1996. Biologia da reprodução de peixes teleósteos: teoria e prática. Maringá, EDUEM, 169p.

Zaniboni-Filho, E., S. Meurer, O. A. Shibatta \& A. P. O. Nuñer. 2004. Catálogo ilustrado de peixes do alto rio Uruguai. Editora da UFSC: Tractebel Energia, 128p.

Zaniboni-Filho, E., A. P. O. Nuñer, D. A. Reynalte-Tataje, S. HermesSilva \& S. Meurer. 2008. Alterações espaciais e temporais da estrutura da comunidade de peixes em decorrência da implantação do reservatório de Itá (alto rio Uruguai). Pp. 21-48. In: Zaniboni-Filho, E. \& A. P. O. Nuñer (Eds.). Reservatório de Itá. Estudos ambientais, desenvolvimento de tecnologias de cultivo e conservação da ictiofauna. Florianópolis, Editora da UFSC, 198p.

Wootton, J. H. 1999. Ecology of teleost fish. Kluwer Academic Publishers, The Netherlands, 386p.

Submitted January 25, 2010

Resubmitted June 13, 2011

Accepted October 31, 2011

Published March 30, 2012 